This is an Accepted Manuscript of an article published by Taylor \& Francis in South Asia: Journal of South Asian Studies on 18 August 2015, available online: https://doi.org/10.1080/00856401.2015.1051202

Accepted version downloaded from SOAS Research Online: $\underline{\text { http://eprints.soas.ac.uk/31507/ }}$

\title{
Booklets and Sants: Religious Publics and Literary History
}

\section{FRANCESCA ORSINI, School of Oriental and African Studies, London, UK}

The story of print and religious publics in colonial India has largely been told as one of reformist groups and religious polemics. But this covers only a small part of the story of religious print, which extends well beyond reformist groups. This essay focuses on the most systematic and long-lived project of publishing Sant orature (bani), the Santbānī-Pustakmālā of the Belvedere Press, Allahabad. It examines its scope, aims, and methods as well as its religious orientation and conceptualisation of a religious-devotional public in early-twentieth-century North India. Halfway between oral bhajan groups and the scholarly publications of the collected works (granthavali) of Sant poets, throughout the twentieth century the Belvedere Press booklets have commanded tremendous currency as religious print-objects in the Hindi devotional public sphere. The results of one publisher's effort and investment, and of significant reorganisation of material from manuscript sources, these booklets have been extremely popular and lasting products in the extensive market for religious material, clearly a crucial technology for individual and group religious practice (bhajan), before which the lineages' own publishing efforts pale into quasi-insignificance.

Keywords: Sant poets, Bhakti/devotion, print, booklets, religious publics

The story of print and religious publics in colonial India has largely been told in connection with reformist groups and religious polemics, yet anyone who has spent any time in the British Library calling up Vernacular Tracts (VT) cannot have failed to notice the large amount of religious publications of all hues that came out in the late nineteenth and early twentieth centuries. ${ }^{1}$ Persian Sufi risalas, Urdu munajat, Hindi bhajans and pothis, Sanskrit texts, religious

\footnotetext{
${ }^{1}$ As I suggested elsewhere, 'Strictly speaking, commercial publishing in North India includes the production and marketing of textbooks, religious books, and books for entertainment, since the same commercial publishers printed them all. Religious publishing spanned a wide range, from canonical texts, booklets of prayers and religious songs, polemical tracts, religious periodicals, and the texts of local or sectarian traditions. It forms at least another history of print in North India, just as substantial in terms of
} 
books were published both by specific khanqahs and maths (monasteries) and by generic publishers. ${ }^{2}$ Studies in the 1990s focused on religious reform and polemics ${ }^{3}$ and on the use of print for competitive and apologetic purposes, initially in connection with Christian missionaries and Hindu and Muslim reformers (who were also viewed as the first to draw up expansive visions of national religious publics), though it became increasingly evident that in fact both 'traditionalists' and 'reformists' shared discourses, strategies, and technologies, including print. ${ }^{4}$ More recently, Nile Green’s Bombay Islam (2011) has shown that in colonial Bombay the world of Islamic print and publishing was constituted by both pan-Indian and transnational reformers and by small 'franchises' of local and regional saints and shrines. The result was an array of old and new texts and forms of address, which he showed combined to produce hybrid forms for the faithful in the colonial metropolis, forms that repay close individual study. ${ }^{5}$

This essay tells a similar story. Against the backdrop of early efforts at publishing Sant orature (bani), ${ }^{6}$ it focuses on the most systematic and long-lived project, the Santbāni-

bulk and variety of output, and as crucial in creating a reading public. But it raises issues of content, audience, and religious transformation that the present book could not begin to address'. Francesca Orsini, Print and Pleasure: Popular Literature and Entertaining Fictions in Colonial North India (Ranikhet: Permanent Black, 2010), pp. 3-4, emphasis added.

${ }^{2}$ For example, Gayaprasad booksellers of Chowk, Gorakhpur, sold bhajans and Krishna pads at four and a half annas; songbooks like Chautāl Basant Bahār and Holī Bahār and Anūthī Kajlì ranged between one and a half and three and a quarter annas; a collection of barahmasas at two annas; an Urdu-English primer at two and a quarter annas; and syllabaries in Devanagari and Urdu for half an anna or even less. Customers or hawkers who bought four books received a fifth one free. See Chautäl Sangrah, held in Bharati Bhavan Library, Allahabad.

${ }^{3}$ Kenneth Jones (ed.), Religious Controversy in British India: dialogues in South Asian languages (Albany: State University of New York Press, 1992).

${ }^{4}$ Vasudha Dalmia, The Nationalization of Hindu Traditions :Bhäratendu Hariśchandra and nineteenth-century Banaras (Delhi: Oxford University Press, 1997).

${ }^{5}$ Nile Green, Bombay Islam: The Religious Economy of the West Indian Ocean, 1840-1915 (Cambridge: Cambridge University Press, 2011).

${ }^{6}$ The term orature reverses the tendency to consider oral literature and traditions as inferior or marginal to literature and underscores the oral and aural qualities of much literary production and experience; written 
Pustakmālā of the Belvedere Press. I examine its scope, aims, and methods as well as its religious orientation and conceptualisation of a religious-devotional public in early-twentiethcentury North India. Halfway between oral satsang groups and scholarly collected works (granthavali) of the Sant poets, the Belvedere Press booklets commanded tremendous currency as religious print-objects in the Hindi devotional public sphere throughout the twentieth century. The results of one publisher's effort and investment, and of his significant reorganisation of material from manuscript sources, these booklets have been extremely popular and lasting products in the extensive market for religious material, clearly a crucial technology for individual and group religious practice (bhajan), before which the lineages' own publishing efforts pale into quasi-insignificance.

\section{Sants into Print}

We know that the words of North Indian Sants-charismatic persons of spiritual accomplishments who delivered their message and teachings through songs and religious discourse ('do not consider this my song, consider it my thinking on Brahma’, Kabir famously said) — circulated for centuries both orally and in manuscript form in very different formats as singers' notebooks and lineage books (pothi or granth). ${ }^{7}$ And while lineages and the monasteries (maths) and seats (gaddis) they established were the chief agents in the systematic collation of Sant aphorisms, song-poems, and biographies-a crucial element in the constitution of the

literature, from this perspective, is but a part of orature. See Ngugi Wa Thiong'o, 'Notes Towards a Performance Theory of Orature', in Performance Research, Vol. 12, no. 3 (2007), pp. 4-7.

${ }^{7}$ See W.M. Callewaert and Mukund Lath, 'Musicians and Scribes', in The Hindi Songs of Namdev (Leuven: Departement Oriëntalistiek, 1989), pp. 55-117; Christian L. Novetzke, Religion and Public Memory: A Cultural History of Saint Namdev in India (New York: Columbia University Press, 2008); and Tyler W. Williams, 'Sacred Sounds and Sacred Books: A History of Writing in Hindi', unpublished PhD thesis, Columbia University, 2014. 
archive-their songs circulated orally beyond the panths (communities) through the agency of singers and in informal bhajan circles, where people got together, generally in the evenings, and sang devotional songs together with the accompaniment of cymbals and a drum, still a widespread practice and the main medium of circulation for devotional words. The Hindi poet Nirala's 'discovery' that in the 1920s illiterate Dalits in his own village had a deep and sophisticated embodied knowledge and aesthetic appreciation for Sant orature-indeed deeper and more sophisticated than the high-caste 'Chaturvedi intellectuals' in the cities-finds powerful expression in his sketch 'Chaturi the Cobbler'. ${ }^{8}$

The transfer of the bani of Awadh Sants from the oral and manuscript traditions into print took place at the crossroads of quite different trajectories of multiple actors: European and Indian Christian missionaries, British Orientalists at Fort William College and in provincial administration, Hindi scholars and literary institutions, commercial publishers like the Belvedere Press or the Venkateshwar Press in Bombay, lineage holders, and Bengali literary figures like Kshiti Mohan Sen and Rabindranath Tagore. Unsurprisingly, the material product of these interventions also differed, though we see similarities in format and agenda emerge, partly because these actors were responding and reacting to one other.

For missionaries and colonial scholars-administrators, it was the religious position and message of the Sants, and of Kabir in particular, that drew their attention, as well their popularity with the North Indian masses. ${ }^{9}$ Already the Italian Capuchin friar Marco della Tomba, who was

\footnotetext{
${ }^{8}$ S. Tripathi Nirala (N. Naval, ed.), 'Caturī Camār', in Nirālā Racnāvalī, Vol. IV (New Delhi: Rajkamal Prakashan, 1983), pp. 74-83.

${ }^{9}$ As Purushottam Agrawal has recently argued, this shows that it is wrong to consider (and champion) Kabir as a marginal and subaltern voice, a brave but failed religious reformer. Kabir was not a marginal voice but the most popular poet of trading and artisanal classes, both in his time and in the following centuries. See P. Agrawal, Akath Kahān̄̄ Prem Kī: Kabīr kī Kavitā aur Unkā Samay (New Delhi: Rajkamal Prakashan, 2009).
} 
active in north Bihar in the late eighteenth century, had undertaken two (unpublished) translations of 'Cabirist' texts and had sought to understand their religious philosophy. ${ }^{10}$ But the first time Kabir's poems appeared in print was in a lithographed anthology published in Calcutta aimed at providing teaching material for East India Company recruits, William Price's Hindee and Hindostanee Selections (1827). The nineteenth-century bazaar editions that followed consisted of compilations of the works of multiple saint-poets for devotional purposes, with little editorial intervention. ${ }^{11}$ Other early publications were missionaries' translations and editions: E. Trumpp’s 1877 translation of the Guru Granth; the 1890 edition of the Kabir panth's Bïjak by Rev. Prem Chand, a convert and Baptist missionary in Munger (Bihar); and its 1917 English translation by Rev. Ahmed Shah. ${ }^{12}$

The main Hindi literary institution, the Nagari Pracharini Sabha of Banaras (est. 1893), was another major force: its Search for Hindi Manuscripts reports alerted Hindi scholars and the Hindi public to the existence of texts and traditions and provided the building blocks for Hindi literary histories, ${ }^{13}$ while its scholarly editions of Hindi ‘classics' like Shyam Sundar Das’s

${ }^{10}$ Charlotte Vaudeville, Kabir (Oxford: Clarendon Press, 1974); and David Lorenzen, 'Marco della Tomba and the Brahmin from Banaras: Missionaries, Orientalists, and Indian Scholars', in Journal of Asian Studies, Vol. LXV, no. 1 (Feb. 2006), pp. 115-43.

${ }^{11}$ For these and other details about Kabir's printing and critical history I draw upon Vaudeville, Kabir, p. $6 \mathrm{ff}$. She notes that the oldest of the popular editions of Kabir was in a collection with other devotional poems edited by Shankar Haribhai in Gujarati script in 1888, and four editions in Bengali translation with commentary appeared between 1890 and 1910 (p. 23fn). The Benares Light Press in Banaras had already brought out accessible lithographed editions of Kabir, Tulsidas and Surdas in the 1860s. See Francesca Orsini, 'Pandits, Printers and Others. Publishing in Nineteenth-Century Benares', in Abhijit Gupta and Swapan Chakravarty (eds), Print Areas: Book History in India (New Delhi: Permanent Black, 2004), pp.103-38.

${ }^{12}$ Vaudeville, Kabir, pp. 11-12.

${ }^{13}$ The Nagari Pracharini Sabha's reports on its search for Hindi manuscripts mention not only Kabir and Raidas, but also Jagjivan Das and Malukdas, thus placing them within the purview of 'Hindi literature'. See, for example, Shyam Behari Mishra, The Second Triennial Report on the Search for Hindi Manuscripts for the Year 1909, 1910, 1911 (Allahabad: Indian Press, 1914), pp. 182, 270. Mishra was one of the authors of Hindī Navaratna (Nine Gems of Hindi) (1910-11), which included Kabir, and of 
Kabīr Granthāvalī, based on two manuscripts preserved in the Sabha, provided new standards of publication. ${ }^{14}$ At the same time, Ram Chandra Shukla's famously disparaging comments on Kabir and the Sants in his Hindī Sāhitya kā Itihās (1929), which started life as an introduction to the Sabha's Hindi dictionary, provided the impetus for several more positive re-evaluations. This included the foundational monograph Traditions of Hindi Mysticism (1936) by S.S. Das’s student, Pitambar Datt Barthwal, the first scholarly treatment of Sant philosophy and poetry, written in English and quickly translated into Hindi, on which more below. Outside the Hindi-speaking world, the Bengali scholar Kshiti Mohan Sen collected sayings and poems of Kabir from contemporary oral sources and published them in Bengali (Kabir, 1910), and it was from this volume that Tagore selected the poems for his influential translation 100 Poems of Kabir (1914). ${ }^{15}$

The result of this publishing activity was an overwhelming focus on Kabir, with an array of printed books at the top and bottom of the price range-English translations, scholarly editions, and cheap bazaar anthologies. It is against this publishing landscape that Baleshwar Prasad's commercial-devotional printing effort at his Belvedere Printing Press in Allahabad from 1903 onward (he died in 1920 but his sons took over the concern) appears remarkably wideranging and systematic. His Santbani Series or Pustakmālā, which remains in print to this day, included almost fifty titles. In the case of the 'lesser Sants' of the Eastern United Provinces (in boldface in Table 1), in most cases it was until recently the only printed edition of their works. ${ }^{16}$

Miśra-bandhu Vinod (Lucknow: Ganga Pustak Mala, 1928), a comprehensive survey of the Hindi literary tradition that drew extensively on the Sabha's search reports. Should this be Triennial? FO YES

${ }^{14}$ These were based on the Dadu-panthi tradition rather than the Kabir-panthi Bïjak.

${ }^{15}$ For details, see Vaudeville, Kabir; and A.K. Mehrotra, Songs of Kabir (New York: New York Review of Books, 2011).

${ }^{16}$ The Malūkdās Granthāvalī only came out in 2006. See below for details. 


\section{TABLE}

Kabīr Sāhib kā sākhì-sañgrah

Kabìr Sāhib kì śabdāvalī aur jīvancaritr (4 pts)

Kabìr Sāhib kī jñān-gudrī, rekhte aur jhülne

Kabīr Sāhib kī akharāvatī

Dhanī Dharmadās jī kī śabdāvalī aur jīvan-caritr

Tulsī Sāhb (Hathras vāle) kī śabdāvalī may jīvan-caritr (2 pts)

Tuls̄i Sāhb (Hathras vāle) kā Ratna Sāgar may jīvan caritr

Tulsī Sāhib (Hathras vāle) kā Ghat Rāmāyan do bhāgõ mẽ, may jīvan caritr (2 pts)

Guru Nānak Sāhib kī Prāṇ-Sañgalī sațippan, jīvan-caritr sahit (2 pts)

Dādū Dayāl kì Bānī, bhāg 1 [sākhī], jīvan-caritr sahit

Dādū Dayāl kì Bānī, bhāg 2 [śabd], jīvan-caritr sahit

Sundar-Bilās aur Sundardās jī kā jīvancaritr

Palțū Sāhib bhāg 1 - kuṇdaliyā aur jivvan-caritr

Paltū Sāhib bhāg 2-rekhte, jhūlne, aril, kabitt aur savaiy $\bar{a}$

Palțū Sāhib bhāg 3 - rāgõ ke śabd yā bhajan aur sākhiyām
Santbān̄̄

Pustakmālā

Jagjīvan Sāhib kī Śabdāvalī aur jīvancaritr (2 pts)

Dūlan Dās jī kī Bānī aur jīvan-caritr

Carandāsjī k̄ Bānn aur jīvan-caritr (2 pts)

Gharībdās jī kī Bānī aur jīvan-caritr

Raidāsjī kī Bānī aur jīvan-caritr

Dariyā Sāhib (Bihār vāle) $k \bar{a}$

Dariyāsāgar aur jūvan-caritr

Dariyā Sāhib (Bihār vāle) ke cune hue Pad aur sākhī

Dariyā Sāhib (Mārvār vāle) kī Bānī aur jīvan-caritr

Bhīkhā Sāhib kī Bānī aur jūvan-caritr Gulāl Sāhib (Bhīkhā Sāhib ke guru) k̄̄ Bānī aur jūvan-caritr Bābā Malūkdās jī kī Bānī aur jūvancaritr

Gusaīm Tulsīdās kī Bārahmāsī

Yārī Sāhib kī Ratnāvalī aur jūvan-caritr Bullā Sāhib kā Śabdasār aur jīvancaritr

Keśavdās jī kī Amīghūṃt aur jūvancaritr

Dharnīdās jī kī Bānī aur jūvan-caritr

Mīrā Bāī kì Śabdāvalī aur jīvan-caritr

Sahjo Bā̄i kā Sahaj-Prakāśs jīvan-caritr sahit ( $3^{\text {rd }}$ ed.)

Dayā Bā̄ kī Bānī aur jīvan-caritr

Santbānī Sañgrah (2 pts) 


\section{Santbān̄̄ Sañgrah caritr sahit}

\section{The Santbani Booklets}

Compared to the miscellaneous collections of Sant songs and verses that had been in the market since the 1860s, the scholarly editions brought out by the Nagari Pracharini Sabha, or the lineage pothis, the Santbānì-Pustakmālā occupies a distinctive middle ground. These were booklets with a modern look, printed with movable type in codex format (unlike some ritual books like vrat kathas which still imitate the horizontal manuscript format even today), with margins and indents and first-line indexes for easy retrieval of individual items.

\section{NOTE TO TYPESETTER. PLEASE PLACE FIGURE 1 HEREABOUTS}

FiguRE 1. Second edition of Dhan̄̄ Dharmadāsj̄̄ kī Śabdāvalī (Allahabad: Belvedere Press, 1923).

Source: Author's own photograph.

We do not know much about the founder-manager of the Belvedere Press, Baleshwar Prasad, who belonged to an Agrawal service and business family that had moved from Punjab to Farrukhabad and then to Banaras in the nineteenth century. After serving as deputy collector, divan to the Raja of Banaras, and junior secretary to the Board of Revenue, in 1902 he retired and moved to Allahabad, where he set up a steam 
press in Belvedere House, next to the University in the Civil Lines area. ${ }^{17}$ Baleshwar Prasad belonged to the Radhasoami community, and while his publishing efforts clearly reflect the catholic and inclusive approach of the movement, their diffusion went much beyond. ${ }^{18}$ (The business is still in the family.)

Prasad's introduction to the series, which appeared behind the cover of every volume, sheds light on his motives, aim, and methods. Regarding motivation, he speaks of retrieval and service to a generic community of readers (sarvasādhāran)—a term we shall return to in the next section. Prasad then stresses the effort and investment put into finding, copying, and collating the manuscripts in proper editorial fashion. The term he favours for the Sants is a generic one, mahatma, and while his statement and the short biographies within each booklet talk at length of the Sants' different communities (sampraday, panth) and provide lineage tables, the statement also reveals a strong standardising and generalising impulse, so that any theological difference or specificity of focus, or competition among Sants and communities, is erased:

The motivation for publishing the Santbani Book Series is to save the $b \bar{a} n \bar{\imath}$ and preaching/message (upadeś) of the world-famous mahatmas from disappearing. Among the bāniss that we have printed so far, several had never been printed before and some had been printed in such fragmented (chhinnbhinn) and unorganised way that prevented one from drawing full benefit.

In the last five years we have, with great effort and at great expense, asked for rare manuscript books and scattered verses from near and far away (deśdeśäntar); we either collect the originals or have copies made, and this activity is still going on. If possible we collect and print the whole texts

\footnotetext{
${ }^{17}$ Details in the family history are taken from the book Agravāl Jāti kā Itihās, Pt. 2 (Bhanpura, Indore State: Agrawal History Office, 1939), as reproduced on the Belvedere Printing Works website [http://www.belvedereprintingworks.com/family-history.html, accessed 15 Apr. 2014]. All translations in this essay are mine.

${ }^{18}$ Mark Juergensmeyer, 'The Radhasoami Revival of the Sant Tradition', in Karine Schomer (ed.), The Sants: Studies in a Devotional Tradition of India (Delhi: Motilal Banarsidass, 1987), pp. 329-55.
} 
(granth) and choose from their miscellaneous verses those pad/songs that will be beneficial to the general public (sarvasādhāran ke upkārak). No book is published without comparing several scripts and without proper emendation, unlike the books others publish without any understanding and any checking (besamajhe aur be jāmche). In correcting the spellings we ask knowledgeable followers of the panth of the mahatmas who authored the texts for help, and in choosing the words we are mindful that they should be in accordance with the taste of the general public (sarvasādhāran ki ruchi) and should be attractive and heart-piercing, so that the heart may be pure and there be no need to avert one's eye.

This book series has been published for several years and any shortcomings are gradually being remedied. We are providing glosses for difficult and rare terms, and printing a biography of the mahatma in question alongside the text, as well as short accounts and wonderful occurrences (kautuk) in footnotes for the devotees and great men whose names occur in the $b \bar{a} n \bar{\imath} s .{ }^{19}$

While Baleshwar Prasad shares a widespread perception of the fragility and perishability of oral traditions and appears keen to echo the Sabha's search efforts and scholarly standard of publication, his intended audience was not the Hindi literary public but the devotional general public, who would benefit from reading and singing any of these works as part of either individual or collective sadhna.

It is instructive to compare these booklets to Mahātmāo $k \bar{\imath} B \bar{a} n \bar{\imath}$ (1933), the printed edition of a manuscript that must have been a major source for Baleshwar Prasad. ${ }^{20}$ The editor of the volume praised Mahant Ram Baran Das of the Banvari Sahiba

\footnotetext{
19 'Manager, Belvedere Press' [Presumably Baleshwar Prasad], 'Nivedan', Gulāl Sāhib kī Bānī, Jivvan-Caritra Sahit (Allahabad: Belvedere Press, 1910), pp. ii-iii. The sentiments were expressed in the subtitle as well: 'jismẽ un mahatmaõ ke ati manohar aur Bhakti baṛhāne vale pad aur sākhiyām śodh kar mukhya mukhya añgõ mẽ rakkhī gaī haĩ, aur gūṛh śabdõ ke arth va sanket bhī not mẽ likh diye gaye haĩ (tr. 'in which the extremely attractive and devotionincreasing songs and couplets are given after correction and arranged according to main categories, with the obscure words explained in footnotes'). Please confirm this is a translation of the subtitle FO YES

${ }^{20}$ Ram Lagan Lal (ed.), Mahātmāã kī Bān̄ì (Bhurkura, Ghazipur: Ram Baran Das, 1933). The book was printed in Banaras by Baijnath Das; I have a facsimile version. The recent volume Rām Jahāj (New Delhi: Naman Prakashan, 2005) published by Dr. Indradev, 'former Principal of Shri
} 
lineage in Bhurkura (Ghazipur)—who had just established a Sanskrit pathshala in Bhurkura—for his generosity in sponsoring the printing of the book, which was sure to ‘benefit all good people’ (n.p.). The thick, 483-page book was therefore a publication sponsored by the Mahant that reproduced in its entirety the 'old' and authoritative manuscript (pothi) preserved at the monastery. In the Bhurkura volume all the poems are numbered sequentially, starting chronologically with the earlier gurus who had slim oeuvre such as Bavari Sahiba (one poem), Biru Saheb (two poems), Yari Saheb (twenty), Shah Faqir (seven), and Keshodas (ten). The longer oeuvre of Biru, Bula, Jagjivan, Dulan, Gulal, and Bhikha is instead grouped by raga and by genre (e.g. jhulna, arill), often with similar compositions by different authors next to each other, an arrangement that may have corresponded to the rhythms of communal ritual and singing. Although the editor accompanied the text with a set of illustrations, individual biographies, a first-line index, and occasional glosses in the style of the Belvedere Press (while the spellings tend to be more Sanskritised), the result was a very different, bulkier and less agile book, and one that does not seem to have been reprinted or circulated widely.

Whether the Bhurkura math brought out the volume in (silent) competition with the Belvedere Press booklets or not, it seems clear that the Belvedere Press rearrangement of the Mahātmāõ ki Bānī into individual portable booklets along a standard thematic pattern and with a handy apparatus was much better suited to, and successful in, reaching out to modern devotees far beyond those who belonged to that specific community.

Mahant Ramashray Das Graduate College, Bhurkura, Ghazipur', appears to be a reprint of this book, though newly typeset and with extensive introductions by the editor and a subtitle that calls the community Satnami rather than Bavri ('Nirgun Satnāmì siddhapīth, Bhurkurā se sambaddh gyārah santõ kī bāniyõ kā sankkalan'), perhaps the result of a realignment of the panth? 
Indeed, arguably the very doctrinal blandness of the enterprise facilitated diffuse and border-crossing readership. You did not need affiliation, initiation, or commitment to a Sant lineage to use and enjoy the poetry. Similarly, despite the fact that we can see some Sants inclining towards certain oral forms, language registers, and poetic strategies rather than others-Gulal towards Hori and spring songs, Bhikha and Bula towards Bhojpuri, Malukdas towards single-metaphor poems - the Santbani booklets de-emphasise any such specificity. All the Sants fit the same pattern, all the volumes follow the same arrangement (thematically by anga and then by genre), and all their verses are 'attractive, devotion-arousing, and beneficial to the general public' in a similar way. ${ }^{21}$ These very portable booklets could circulate singly and inexpensively—-they still do—or be bound by readers into more durable volumes (Figure 2).

NOTE TO TYPESETTER. PLEASE PLACE FIGURE 2 HEREABOUTS

FIGURE 2. Collected and bound Belvedere Santbani booklets

Source: Courtesy of Vasudha Dalmia. Author's own photograph.

Even now, the family speaks of individual sadhus and devotees from distant regions who drop in to buy individual booklets, of bulk orders from bookstores and monasteries, and of the brisk commerce that takes place at religious fairs and railway stalls. This is a varied and diffuse distribution circle that extends all over North India, far beyond the

\footnotetext{
${ }^{21}$ The reference to the editorial purging of inappropriate words must remain obscure in the absence of manuscripts or oral tellings that reveal alternative readings, though intriguingly Gulal's caste-specific song-poems (on the four varnas and then on kayath, ahir, baniya, khatri, sonar, lohar, bhat, pandit, molana, sanyasi, bairagi, several kinds of yogis-yogi, jangam, dandi, nirbani-darvesh, teli, and kalvar) are not included in the Santbani booklet of his works, Gulāl Sāhab kī Bānī (Allahabad: Belvedere Press, 1932). See Mahātmāõ kī Bānī, pp. 346-72.
} 
domain of Hindi literary books and the collected works of Sants. ${ }^{22}$ If one of the great puzzles of the Hindi-Urdu publishing boom of the second half of the nineteenth century is its mismatch with the extremely sluggish growth in literacy and formal education statistics, I have argued elsewhere that the great expansion in cheap publications requiring only minimal literacy suggests that many people acquired literacy not at school, but 'on the side'. ${ }^{23}$ That many religious publications, Santbani booklets included, belong to this category suggests that many religious/devotional readers were neo-literates. And if Chaturi the cobbler's descendants are literate today and still sing Sant songs, these are the booklets they will purchase.

\section{'Beneficial to the general public': Santbani Booklets and Religious Publics}

There are many līlās and miracles (chamatkār, elsewhere karāmat) regarding Bhikha Sahab and it is unnecessary to reproduce them all here because people invent so many stories after the Mahatmas disappear which in the eyes of reasonable people (samajhdār) do not increase one jot the Mahatma or devotees' glory despite the fact that ordinary people are enthusiastic about them ( $v \bar{a} h v \bar{a} h$ karte haĩ). Even so, here are two or three such stories. ${ }^{24}$

Let us return for a moment to Prasad's statements-his claim in the introduction to the Santbani booklets that he had selected songs that would be 'beneficial to the general public' (sarvasādhāran ke upkārak) and, in the quote above, his contrast between 'reasonable people' and 'ordinary people'. Did Prasad see himself as part a modernising elite and wished through his booklets to reform and improve a credulous public—an

\footnotetext{
${ }^{22}$ Interview with Anupam Agrawal, present owner of Belvedere Printing Works, Allahabad, April 2013.

${ }^{23}$ Orsini, 'Introduction', Print and Pleasure.

${ }^{24}$ Bhīkhà Sāhib kī Bānī (Allahabad: Belvedere Press, 1919), p. 2. Sāhib correct, corrected fn 57 Is this the same as fn. 57 ? FO YES
} 
example of a 'split public', extending Rajagopal's useful concept? ${ }^{25}$ Or does the last sentence-'Even so, here are two or three such stories'—suggest that this was just a gesture, and that the modern devotional public easily brushed aside scepticism and social divisions between educated and 'ordinary’ people?

Let us start with sarvasādhāran, a term generally used at the time to stress the openness and inclusivity of the 'public' (rather than the more cultural and communityloaded term $j \bar{a} t i$, which instead emphasised internal unity). Sarvasādhāran could be used in a reformist sense — the one seemingly implied here—or in a radical sense, to oppose restricted or hierarchical understandings of public. ${ }^{26}$ But what does sarvasāadhāran mean in this particular context? Three aspects appear significant: first, publishing as publicity, making available in reliable editions valuable words that would otherwise disappear with frayed manuscripts in individual maths. ${ }^{27}$ Booklets made verses and songs, so far only available either orally, in manuscripts, or in expensive and unwieldy scholarly editions, accessible in agile and portable format for personal or group devotion. But rather than viewing the printing of these booklets as a transition from orature to print and (silent) reading, we need to bear in mind that the booklets were and are meant to serve individuals or groups who recite or sing these verses. In this respect the booklet should be

\footnotetext{
${ }^{25}$ Arvind Rajagopal, 'A "Split Public" in the Making and Unmaking of the Ram Janmabhumi Campaign’, Politics after Television (Cambridge: Cambridge University Press, 2001), pp. 151-71.

${ }^{26}$ See Francesca Orsini, 'What Did They Mean by "Public"? Language, Literature and the Politics of Nationalism', in Economic \& Political Weekly, Vol. 34, no. 7 (13-19 Feb. 1999), pp. 40916.

${ }^{27}$ This emphasis is visible in the edition of the collected works of Malukdas recently sponsored by the successor to the gaddi, Yogiraj Nanakchand: 'As the Mahant of the holy gaddī...I consider it my duty to publish a reliable (prāmānik) collection of Malukdas's unavailable literature so that it can reach the general public (jan sādhāran)'. See 'Do śabd', in Baldev Vanshi (ed.), Sant Malūkdās Granthāvalī (New Delhi: Parmeshwari Prakashan, 2006), p. 5.
} 
rather understood as a technology of orature and an extension of it. ${ }^{28}$ Second, Santbani booklets did make the words of the Sants available beyond the purview of individual sampradays. While the Santbani project reflects Radhasoami attitudes (and today songpoems by Sants like Malukdas are most likely to be quoted and commented upon by Radhasoami preachers), the booklets themselves did not carry or propound any obvious Radhasoami affiliation. They addressed and served a general public of devotees. Of course, the fact that Sants largely shared critiques of caste hierarchy and of other forms of organised religiosity made such general address easier (see also footnote 21 above). Third, the material form in which we find the booklets and the fact that wealthier readers bound these inexpensive booklets into handsome volumes underscore the fact that the audience the booklets reached was a wide one that encompassed both educated and ordinary readers. Finally, Prasad's disavowal of hagiography and belief in miraculous stories should arguably be read as only a gesture—a gesture repeated but never complete ('Even so, here are two or three such stories'). This remains true to this day: whether it is scholarly treatments, critical editions like Baldev Vanshi’s recent Malūkdās Granthāvali (2006), the Santbani booklets, the Mahātmāõ kī Bānī, or a contemporary pravachan on a Malukdas poem, there is always an initial gesture towards historicity: 'We don't have the full history...sources were written quite a bit later...' But after this initial gesture, hagiographies are retold with full fervour. ${ }^{29}$ So while arguably by disaggregating pothis into individual authors the Santbani booklets encouraged a sense of individual authorship and historical personhood, it was and still remains a historical personhood invested with

\footnotetext{
${ }^{28}$ For a similar argument about books as aids to orature and performance, see Novetzke, Religion and Public Memory, Chap. 3.

29 'Satsang Dada Mangharam Jeeti baji Guru pratapse Baba Malukdas', [https://www.youtube.com/watch?v=wukY_6H0SBo, accessed 4 Sept. 2014].
} 
charisma. And despite the editor's mention of separate 'educated' and 'ordinary' readers, the booklet as a technology and an object did not produce a split public. Rather, by making inoffensive claims about the beneficial words of generic 'great souls', the Santbani booklets likely penetrated existing circles of devotional activity, extending their repertoires.

\section{Not Poetic Enough? Orature, Religion, and Literary History}

There is another aspect of this story that intrigues me. While Sants like Malukdas definitely fell within the purview of Hindi literary historians, aided by the Belvedere Press enterprise (it seems hardly believable, but the most comprehensive scholarly study of North Indian Sants, Parashuram Chaturvedi’s Uttar Bhārat kī Sant Paramparā (1950), drew upon the Santbani booklets instead of manuscripts for the Awadh Sants), their literary status has remained much shakier. If Awadh Sants have been discussed and valued it has been as religious reformers and teachers, not as poets. Why so?

Colonial interest in Bhakti, Vijay Pinch has argued, stemmed from a number of motivations. It paralleled the devotionalist ethic of late Victorian Britain and reflected a shift among Orientalists in India to a 'more comparative posture' in the 1860s and 1870s after the 'confident evangelism of the first half of the century'. ${ }^{30}$ Moreover, if Orientalists believed that religion was crucial to any understanding of India, in polemic with Sanskrit Orientalists scholar-administrators like George A. Grierson believed that studying Bhakti yielded a better understanding of modern India—and earned the subjects' trust:

\footnotetext{
${ }^{30}$ Vijay Pinch, 'Bhakti and the British Empire', in Past \& Present, Vol. 179, no. 1 (May 2003), p. 175. Note to Mimmy: Journal title is correct
} 
Believe one who has tried it, that the quotation of a single verse of Tulasi Dāsa or of a single pithy saying of the wise old Kabīr will do more to unlock the hearts and gain the trust of our eastern fellow-subjects than the most intimate familiarity with the dialectics of Śankara or with the daintiest verse of Kālidāsa. A knowledge of the old dead language will, it is true, often win respect and admiration, but a very modest acquaintance with the treasuresand they are treasures - of Hindī literature endows its possessor with the priceless gift of sympathy, and gains for hira, from those whose watchword is Bhakti, their confidence and their love. ${ }^{31}$

Bhakti presented British missionaries and scholars with a particularly congenial form of Indian religion. Grierson shared with Bishop Westcott and other missionaries the belief that Bhakti—Kabir included—had derived from the spread of early Christianity. ${ }^{32}$ And even when that particular theory was disproved, Christian vocabulary permeated Grierson's (and others') descriptions of Bhakti, its saints and poems (which he called hymns). Thus for Grierson Bhakti taught 'the fatherhood of God and His infinite love and compassion'; ${ }^{33}$ Krishna worship taught 'the first, and great, commandment of the law; the second—though shalt love thy neighbour as thyself—it hardly touches'; ${ }^{34}$ Tulsidas's devotion 'is directed to a loving, all-powerful God, who offers Himself to His worshippers as the Great Example'. ${ }^{35}$ Following Westcott, who had described Kabir as 'the Indian Luther of the 15th century', ${ }^{36}$ Grierson spoke about Kabir in the idiom of

\footnotetext{
${ }^{31}$ G.A. Grierson, 'Modern Hinduism and Its Debt to the Nestorians', in Journal of the Royal Asiatic Society of Great Britain and Ireland (Apr. 1907), pp. 334-5. Quoted in Pinch, 'Bhakti and the British Empire', p. 181.

${ }^{32}$ Ibid. See also Vaudeville, Kabir, pp. 11-13.

${ }^{33}$ George A. Grierson, 'The Popular Literature of Northern India', Bulletin of the School of Oriental Studies, University of London, Vol. 1, No. 3 (1920), p. 101.

${ }^{34}$ Ibid., p. 102

${ }^{35}$ Ibid., p. 112. Please confirm these 3 references are correct FO checked and corrected

${ }^{36}$ G.H. Westcott, Kabìr and the Kabirpanthis (1908), quoted in Vaudeville, Kabir, p. 22. Grierson, who had already compared Bhakti to the reformation (with a small ' $r$ '), wrote of Kabir that 'He was Musalmān who, attracted by the reformed Hinduism, founded a sect in which Islām and it were combined'. See Grierson's 1918 lecture to the School of Oriental and African Studies,
} 
Reformation: '[t]hat some of [Kabir's] ideas, nay, many of his actual phrases, were borrowed either directly or at second hand from the Gospels cannot be doubted', he argued. ${ }^{37}$

Even Hindi scholars who did not share these Christian views shared some of the same epistemological premises. A 'new' religion like Bhakti could only be described as a derivation, and combination, of elements from earlier philosophies and religions—indeed it had to be so in order to prove that it was a 'real religion'. Similarities called for filiation, whether from Christianity or Vedanta or Sufism. ${ }^{38}$ Particularly in the case of Kabir, 'birth determinism' meant that his birth and upbringing and his thought had to match—how could he know Hinduism and Vedanta so well if he was born a Muslim? ${ }^{39}$ British and Indian modern scholars of Kabir shared this belief, Purushottam Agrawal has recently

'Popular Literature of Northern India', Bulletin of the School of Oriental and African Studies, (1920), p. 118.

${ }^{37}$ Grierson, 'Popular Literature of Northern India', p. 119. Pinch argues that Grierson abandoned his view of the Nestorian Christian origins of Bhakti after James Kennedy and J.B. Keith expressed scepticism and R.G. Bhandarkar's showed evidence of the pre-Christian origin of Bhakti theology in Vaisnavism, Saivism and Minor Religious Systems (1913), but we see in the 1918 speech that Christian vocabulary still governed Grierson’s description of Bhakti. See Pinch, Bhakti and the British Empire', pp. 176-7.

${ }^{38}$ P.D. Barthwal, Traditions of Indian Mysticism, Based upon the Nirguna School of Hindi Poetry (New Delhi: Heritage Publishers, [1936], 1978), p. 15. See esp. Chap. 2, 'The Nirguṇi’s Philosophy', pp.18-89.

39 'Though brought up in a Muslim household', Shyamsundar Das stated, 'the fact that he is steeped in Hindu ideas gestures towards the fact that Brahmin, or at least Hindu, blood flowed in his veins'. See introduction to Kabìr Granthāvalī, quoted in P. Agrawal, Akath Kahānī Prem Kī, p. 158. For Chandrabali Pandey, Kabir was instead a Muslim by birth and a radical Sufi by practice. Hazari Prasad Dvivedi set up an elaborate scheme that accounted for the varied strands of his religious idiom; according to Dvivedi, there had been a caste of Nathpanthi householders in northern and eastern India at the time who were either weavers or beggars, most of whom did not observe caste rules and worshipped a formless god; with the coming of Islam they had gradually converted, and it was in such a family of neo-converted householder jogis that Kabir was brought up. The only problem, Agrawal notes, is that Kabir never called himself a jogi but only a julaha, a kori, or 'neither Hindu nor Muslim'. See ibid., p. 163. Should this be yogi as in fn. 22? FO It's jogi in all early modern Hindi discussions. 
argued, because colonial modern epistemology viewed early modern Indian subjects as mere cyphers of their birth, caste and religion—-thus Kabir must have said what he said because of his background, not out of choice. Why, Agrawal asks, is it so difficult to imagine that the religious ideas of an early modern individual were the result of individual choice? 'It was not necessary to be born or converted into a religion to be familiar with the Nathpanth—people searched through study and satsang, they used their discrimination, they weighed and accepted or rejected it'. ${ }^{40}$ So 'Kabir's discourse and ideas (vaicārikī) is not bound by genealogy', Agrawal argues; 'it is the outcome of the bold quest of a restless individual, it was an individual, rational choice'. Kabir was familiar with current religious idioms (bahushrut, 'well-listened', if not bahu-pathit, 'well-read') ${ }^{41}$ but used them creatively to give expression to his own spiritual journey. It is in this spirit of creativity that we shall explore their poetic religious language below.

The historical view of Bhakti as a direct product or consequence of Islamic 'invasion’ was another premise that British and Indian scholars shared, and their words almost exactly mirror each other's. Thus, according to Grierson, Bhakti came from the South 'in the same century as the battle of Thānēsar' and 'rapidly spread into Northern India, then gasping in its death-throes amid the horrors of alien invasion'; it 'came at this time as balm and healing to a suffering people, and we see this reflected in...lyric poetry'. ${ }^{42}$ Ramchandra Shukla famously opened his chapter on the age of Bhakti with an equally bleak picture of Muslim destruction and Hindu despair. ${ }^{43}$ In his monograph on

\footnotetext{
${ }^{40}$ P. Agrawal, Akath Kahānī Prem Kō, p. 174.

${ }^{41}$ Ibid., p. 312.

${ }^{42}$ Grierson, 'Popular Literature’, p. 101.

43 'With the establishment of Muslim rule in the country there was no place left in the hearts of the Hindu people for pride, self-respect, and enthusiasm. Right before them their temples were
} 
the Nirguna School of Hindi poetry, Pitambar Datt Barthwal also began with this gloomy picture of 'Mohammadan conquest' and a stark polarity between polytheist, idolworshipping Hindus and monotheist, idol-breaking Muslims ('There was thus a vast gulf of hatred separating the two races, that still needed being bridged'). In Barthwal's case, though, Hindu-Muslim hostility emphasised the contrast with the Sants (and the Sufis among Muslims) as men 'above all race-prejudices' who 'viewed this state of things with grave concern.... ${ }^{44}$ The Nirguna School therefore answered the need of the hour; it was the reform movement that Medieval Indian 'urgently needed' that 'would aim at sweeping away all ignorance and superstition, that gave rise to Mohammadan superstition and fanaticism on the one hand and iniquitous social fetters on the other and that stood in the way of communal rapprochement and social equities' ${ }^{45}$ Contemporary echoes would not have been lost on readers in 1930s North India who had witnessed the violent communal riots of the 1920s.

Religious and political questions therefore dominated discussions of Bhakti and the Sants, and even for literary scholars tended to overshadow serious engagement with their poetry. Yet even when they did discuss the poetry, they found it not to their liking.

destroyed, the statues of gods were demolished, and their venerable persons were humiliated, and there was nothing they could do'. See R.C. Shukla, Hindī Sāhitya kā Itihās (Kashi: Nagari Pracharini Sabha, [1929] 1988), p. 15, quoted and translated in Navina Gupta, 'The Politics of Exclusion? The Place of Muslims, Urdu and its Literature in Rāmcandra Sukla's Hindī Sāhitya kā Itihās', in H. Harder (ed.), Literature and Nationalist Ideology: Writing Histories of Modern Indian Language (New Delhi: Social Science Press, 2010), p. 268. Translation slightly changed.

${ }^{44}$ Barthwal, Traditions of Indian Mysticism (1978), p. 8. Please confirm this is p. 8 FO YES

45 'Thus did the needs of the times find their realisation in the Nirguna movement initiated by Kabīr. Nānak, Dādū, Prāṇanāth, Malūkdās, Palaṭū, Jagjīvan dās, Śibdayāl, Tulasī Sāhib and a host of other Sants took up his mission from time to time and worked for the propagation of this movement for unity and equity'. Ibid., p. 17. As is well known, Ramchandra Shukla did not share this opinion of the Sants, whom he considered - in line with Tulsidas - as spreading radical centrifugal ideas that went against the need of the hour, which was for unity among Hindus. Should this be Sants rather than saints? FO YES 
'How earnestly one wishes that these Nirguṇīs knew and cared for the ordinary rules of grammar and prosody if not of rhetorics. Even a little bit of polish would have immeasurably enhanced the charm of their utterances', lamented Barthwal, and singled out the Dadupanthi Sundardas as 'the only educated person among them perhaps'. ${ }^{46}$ 'After acknowledging the greatness of [Kabir's] personality, when it comes to his poetic art the pen hesitates a little', wrote the Mishra brothers, who had placed Kabir among their 'nine jewels' of Hindi literature, but who in literary terms positioned him after Tulsidas and Surdas, 'between Matiram and Chandbardai'. They admitted that about 'a hundred pages' of Kabir's poems were of high quality, while the rest was repetitive and dull $(f i k \bar{a}) .{ }^{47}$ Echoing Barthwal, they conceded that '[h]ad Kabir Sahab composed books (granth) from a literary perspective, there is no doubt that given the level of his composition he could have written excellent ones. He had all the qualities of a good poet (satkavi), he only lacked the will. He did not even want to be a good poet, he was a sermon-giver and a religious preacher' ${ }^{48}$ Thus Hindi scholars chose to think that Kabir and the other Sants could have been poets if they had wanted, but that poetry was not their aim.

Intriguingly, both Barthwal and the Mishra brothers acknowledged that Tagore's translation had bestowed recognition as well as literariness on Kabir's verses. According to Barthwal, '[t]hough naturally enough poetic ideas cannot be faithfully translated into a foreign tongue, yet in fact most of the poems of the Nirgunī poets appear grander in translations than in the original, for it is not only poetic "aroma" but also crudeness of

\footnotetext{
${ }^{46}$ Ibid., p. 222.

${ }^{47}$ G.B., S.B., and S.D.B. Mishra, Hindī Navaratna (Hyderabad: Ganga Granthaghar, [1955], new edn. 1975), p. 421.

${ }^{48}$ Ibid., p. 491.
} 
expression that evaporates in the process' ${ }^{49}$ 'Didactic religious treatises' was Grierson's verdict on Kabir's poems, whereas he had warmer words for Surdas, Tulsidas, Vidyapati and even Bihari. ${ }^{50}$ 'Crudeness of expression', 'ruggedness', 'didacticism', lack of knowledge of poetic rules—or, in positive terms, 'well-arranged and beautiful language', 'here and there you can find [in Maluk Das] poetic construction (pad vinyās) and kavitt like in good poets'; ${ }^{51}$ even when Hindi critics meant to praise the artistry of Sant poets, they damned them with faint praise. Why was it so difficult—even for those who were critical of old poetic tastes and were looking for models to establish new ones, and who appreciated the content and popularity of Sant poets—-to find the vocabulary to appreciate Sant poetic aesthetic?

For the Mishra brothers, with their keen taste in courtly poetry (riti), the answer is simple: Sant poets did not follow the established formal rules of poetry and did not know, or care, to play that particular poetic game. In the case of Barthwal and the Romantic ideals that underwrote his views of poetry, he could praise Sant poetry for its 'artlessness' as 'natural poetry', and the direct and unsuppressable 'experience of inner life'. ${ }^{52} \mathrm{He}$ approved of their 'observation of nature', of some 'delightfully melancholy images', of the symbolic love songs, but this ideal not only pushed Sants' poems towards Tennysonian maudliness, but also made him distinguish between 'true poetry' and 'mere

\footnotetext{
${ }^{49}$ Barthwal, Traditions of Indian Mysticism, p. 223. 'There is no doubt that Kabir Sahab was a poet of high quality. The jewel poet of contemporary India himself, Rabindranath Tagore, has recognized him as a good poet and translated his verses (pad) in English. Even from reading that book of translations Kabir's literary height (gaurav) transpires'; G.B., S.B., and S.D.B. Mishra, Hindī Navaratna, p. 491.

${ }^{50}$ Grierson, 'Popular Literature’, p. 119.

${ }^{51}$ Shukla, Hind̄̄ Sāhitya kā Itihās, p. 63.

${ }^{52}$ Barthwal, Traditions of Hindi Mysticism, p. 225.
} 
didacticism. ${ }^{53}$ As a result, he conducted surgical operations in an attempt to divide good verses from bad ones. ${ }^{54}$ The combination of deep philosophical-religious meanings and aesthetic appreciation that Nirala recognised in Chaturi's illiterate but perceptive understanding of Sant poetry lacked where strong ideas of poetry held sway.

Yet while early modern and modern canonical lists of Hindi poets snubbed Awadh Sant poets ${ }^{55}$ - with the exception of Kabir in modern times- the Sant poets of Awadh certainly viewed themselves as poets, and what they did as poetry, kabitāi. ${ }^{56}$ As Bhikha wrote in his autobiographical poem, it was through 'writing, learning, and reading', and singing many rekhta, kabitta, sakhi, sabda and dhrupad that he had found his guru:

bahu rekhta aru kabitta sākhī sabda sõ mana māna soi likhata sīkhata parhata nisu dina karata Hari guna gāna. (8) ika dhrupada bahuta bicitra sonata bhoga pucheu hai kahām niyare Bhựkựā gram jāke sabda āpe hai tahām. (9) ${ }^{57}$

So many rekhta, kabitta, sakhi and sabda I wrote, learnt and read in my mind, night and day I praised Hari/the Lord. I heard a strange dhrupada song and asked — where is it from? The sabda is by some who lives near Bhurkura village.

\footnotetext{
${ }^{53}$ Ibid., p. 227

${ }^{54}$ Ibid., p. 228. But, as A.K. Ramanujan cautions, “"spontaneity” has its own rhetorical structure'. See A.K. Ramanujan, Speaking of Siva (London: Penguin Books, 1973), p. 38.

${ }^{55}$ Sant poets were beyond the pale of literariness for early modern Hindi treatises: both Lal Kavi's Avadha Bilāsa (Delights of Ayodhya) (1675), a Ram-rasik text composed in Ayodhya, and Bhikharidas's Kāvya-Nirnaya (Discrimen of Poetry) (1746), mention Tulsidas and Surdas as poets, but not Kabir. The first 'Hindi tazkira', Shiv Singh Sengar's Śiv Simh Saroj (1878), does include Malukdas, however briefly, but quotes a courtly verse that seems at odds with his poetic voice. Please confirm this spelling is correct FO YES

${ }^{56}$ Malūkdās kī Bānī (Allahabad: Belvedere Press, 1920), p. 31. FO YES

${ }^{57}$ Bhīkā Sāhib kī Bānī (Allahabad: Belvedere Press, 1919), p. 12.
} 
Yet, partly for reasons of caste and class, modern Hindi literary scholars preferred the old courtly aesthetic to the 'rough' aesthetic of Sant orature. And appreciation for the humanist values of the Sants thus took the place of literary evaluation.

\section{Conclusions}

Awadh Sant orature, which was such an important and vibrant part of local religious and poetic life well into the twentieth century, did make it into the world of print. This essay has explored the material form the Sant poets' oeuvre took in print, the agents involved in this transfer, and the religious public the printed books envisaged. Apart from the material changes involved in the process, we also saw the larger religious and literaryhistorical discourses the Awadh Sants were fitted into. So while the most significant agent was a commercial publisher of devotional disposition, his enterprise needs to be read at the intersection of a number of initiatives and discourses around Bhakti and the Sants at the time-by missionaries, Orientalists, Hindi literati, and literary institutions.

The Belvedere Press Santbani series has been extraordinarily successful and longlived, and much more successful than the lineages’ own publications in reaching out to a broader religious public. The booklets have continued to spread the Sants' words independently of the varying fortunes of their panth communities for over a hundred years, and have allowed the Belvedere Press to survive. Yet while the Santbani series has ensured some visibility and long-term life in print for these poet-saints and their words, and I have argued that the cheap booklet format should be viewed as a technology aiding

orature rather than superseding it, in terms of general visibility it has had a kind of penumbral existence. In Hindi literary histories and in religious compendia, the limited 
and generic coverage of Awadh Sants means that they are more often known as names than as authors—what Genette calls 'paratext without a text'. ${ }^{58}$ In fact I call Malukdas, Dharnidas, Gulal Saheb, Bhikha Saheb, Paltudas, Jagjivandas, and so on 'three-line poets', because literary histories usually contain little beyond a short biography with hagiographical tales and a list of their works. Further, by packaging the Sants as generic mahatmas, retrospectively the Santbani series has diluted and generalised the bani of the Sants. From a literary perspective, although Belvedere Press booklets have remained the only source for the Sants' oeuvre, on the whole they have failed to alert readers and students of Hindi literature of the poetic value and historical significance of this poetry. The original Santbani project aimed at suturing differences between literary and devotional poetics, between oral and manuscript traditions and print, and between panthcentred and 'generic' devotional publics. But whereas older bound collections indicate that the Belvedere Press booklets reached both 'educated' and 'ordinary' readers, at present their low-quality paper and smudged printing suggests that the booklets now cater primarily to 'ordinary' devotees. Whether an influential and modernising organisation like the Radhasoami panth has repackaged them for their middle-class followers remains to be seen.

\footnotetext{
${ }^{58}$ Gerard Genette, Paratexts (Cambridge: Cambridge University Press, 1997).
} 